\title{
Day by day telemetric care of patients treated with cardiac resynchronisation therapy: first Polish experience
}

\author{
Agnieszka Liberska, Oskar Kowalski, Michał Mazurek, Radosław Lenarczyk, Ewa Jędrzejczyk-Patej, \\ Katarzyna Przybylska-Siedlecka, Monika Kozieł, Stanisław Morawski, Tomasz Podolecki, \\ Jacek Kowalczyk, Patrycja Pruszkowska, Sławomir Pluta, Adam Sokal, Zbigniew Kalarus
}

Department of Cardiology, Congenital Heart Disease, and Electrotherapy, Silesian Medical University, Silesian Centre for Heart Diseases, Zabrze, Poland

\begin{abstract}
A b stract
Background: Due to the recent rapid increase in the number of patients implanted with pacemakers, cardioverter-defibrillators (ICD), and cardiac resynchronisation therapy devices (CRT), conventional monitoring at specialist clinics is becoming increasingly difficult. The development of technology has enabled remote device monitoring with the use of teletransmission systems.

Aim: To assess the effectiveness of transmission and the possibility of using telemetric data for further clinical management of patients with heart failure (HF) treated with CRT-D.

Methods: The analysis included 305 consecutive patients with chronic HF, New York Heart Association functional classes II-IV, treated with the use of CRT-D by Biotronik or Medtronic in the years 2006-2012. The patients received transmitters, enabling the remote monitoring of the implanted device from the patients' houses. Scheduled reports were automatically sent every month. The triggers for pre-specified emergency alert transmissions were as follows: ventricular tachycardia (VT) or ventricular fibrillation (VF) episodes, CRT-D intervention, ventricular extrasystoles $>110 / \mathrm{h}$, any episode of atrial fibrillation $(\mathrm{AF})$, atrial flutter (AFL) or supraventricular tachycardia, mean heart rate (HR) during, mean 24-h HR, CRT pacing < 95\%, Elective Replacement Indicator, or End Of Service and device malfunction. The all-cause mortality of the study population has been assessed at the end of the follow-up period (mean of 20.5 months).

Results: Devices manufactured by Biotronik were provided to $71 \%$ of the study population, while $29 \%$ received devices by Medtronic. In $97.3 \%$ of cases, the monitors were wireless, fully automatic, and capable of immediate data transmission whenever a pre-specified alert notification was fulfilled. The analysis of long-term outcomes revealed that all-cause mortality of the whole study population was $13 \%$. The effectiveness of report transmission was $98 \%$. During follow-up a total of 31,198 transmissions were received and analysed, which constituted, on average, 4.9 transmissions per patient per month. Among analyses, $30 \%$ were reports generated by scheduled remote follow-ups, and $70 \%$ were caused by unscheduled device alerts. Correct functioning of the system was confirmed; the quality of the received data was $100 \%$. In $63.9 \%$ of patients, decisions based on the information obtained from telemonitoring reports were made to modify the therapy, refer the patients to cardiology or electrophysiology clinics, or hospitalise them urgently. The most common medical reaction was device reprogramming (46.8\%). Pharmacotherapy was modified in $33.7 \%$ of patients: beta-blocker dose increase (25.9\%), anticoagulant treatment inclusion (15.7\%), amiodarone inclusion (1.9\%), or digoxin inclusion (4.5\%). The remaining medical responses were referring patients for atrioventricular junction ablation (8.1\%), VT ablation (2.9\%), or AF/AFI ablation (1.6\%).

Conclusions: Remote monitoring of implantable devices is feasible, safe, and effective in supervising patients with CRT-D devices. Daily-based remote monitoring of a large population of HF patients allows continuous "triage" of high-risk patients and selection of individuals who require urgent intervention.
\end{abstract}

Key words: remote monitoring, cardiac resynchronisation therapy, heart failure

Kardiol Pol 2016; 74, 8: 741-748

\section{Address for correspondence:}

Agnieszka Liberska, MD, Department of Cardiology, Congenital Heart Disease, and Electrotherapy, Silesian Medical University, Silesian Centre for Heart Diseases,

ul. Skłodowskiej-Curie 9, 41-800 Zabrze, Poalnd, e-mail: aliberska@gmail.com

Received: 16.05.2015 Accepted: 19.01.2016 Available as AoP: 26.01.2016

Kardiologia Polska Copyright (C) Polskie Towarzystwo Kardiologiczne 2016 


\section{INTRODUCTION}

Due to the recent rapid increase in the number of patients implanted with pacemakers, cardioverter-defibrillators (ICD), and cardiac resynchronisation therapy devices (CRT), conventional monitoring at specialist clinics is becoming increasingly difficult. This constitutes an enormous challenge for outpatient monitoring systems for individuals with implanted devices. The expert consensus statements from 2008 and 2015 on the management of patients with implantable devices recommend relatively frequent follow-up visits in such cases. The follow-up visits of patients with high-energy devices (CRT-D or ICD) should be more frequent than of those with conventional pacemakers. All implanted devices should be checked within $72 \mathrm{~h}$ after implantation and during the subsequent period of 2-12 weeks in a conventional manner. After that time, the long-term management of patients with ICD or CRT-D should include follow-up visits every 3-6 months, and at signs of battery depletion, every $1-3$ months $[1,2]$. In 2009, the number of cardiac pacemakers implanted per 1 million Europeans was 920, ICD - 144, and CRT - 106. In 2014 this number increased and amounted to 944, 183, and 160 devices, respectively $[3,4]$. This is the reason why telemonitoring has become increasingly popular in recent years. The development of technology enabled remote device monitoring with the use of teletransmission systems. The transmitter that the patient receives during implantation sends data to the central servers of individual companies using GSM or landline transmission. The data are then processed and made available to authorised and trained medical staff. The development of new technologies enables the tracking of very important data provided by the device, including the percentage of atrial, ventricular, and biventricular pacing, temporary and mean heart rate (HR) values, mean patients' activity, arrhythmic episodes, and cardioverter-defibrillator interventions. Moreover, it also continuously provides important parameters concerning the correct functioning of the device itself. Appropriate use of these data may significantly facilitate the care of patients with severe chronic heart failure (HF) and help identify high-risk patients requiring closer monitoring. The current guidelines of the European Society of Cardiology concerning cardiac pacing and resynchronisation therapy recommend the use of remote device monitoring to ensure earlier detection of clinical complications and technical problems in class Ila [5]. In 2014, the results of the IN-TIME study were published [6]. The study group was composed of 333 patients with ICD or CRT supervised with the use of Home Monitoring by Biotronik, while the control group included 331 patients with ICD and CRT supervised in a classic fashion. This was the first trial that showed a substantial mortality reduction of remotely monitored vs. non-monitored patients (mortality rates of $3.4 \%$ vs. $8.75 \%$, respectively, $p=0.004$ ). However, of note is that the IN-TIME trial did not demonstrate any difference in HF hospitalisations between the study groups
( $44 \%$ vs. $47 \%$, respectively, $\mathrm{p}=0.38$ ), nor did it explain the reasons for mortality reduction in the monitored group. It has been suggested that close, everyday monitoring of different device parameters, early detection of atrial and ventricular arrhythmias, and episodes of suboptimal biventricular pacing as well as generally better patient compliance are potential reasons for better outcomes in monitored patients. These and other recently published data indicate that device remote monitoring may significantly improve the care of patients with HF. In our study, we made an attempt to assess the efficacy of telemetric transmissions and the usefulness of such acquired data in further clinical management of CRT recipients.

\section{METHODS \\ Patient selection}

The analysis included 305 consecutive patients with chronic HF, New York Heart Association (NYHA) functional classes II-IV, treated with the use of cardiac resynchronisation therapy (CRT-D) by Biotronik or Medtronic in the years 2006-2012. Patients were referred for CRT-D device implantation on the basis of the European Society of Cardiology guidelines applicable at that time.

The study inclusion criteria were as follows:

- age over 18 years;

- informed consent to the procedure and the telemonitoring of the implanted device;

- symptomatic, systolic HF in NYHA functional classes II-IV despite optimal pharmacotherapy within previous three months;

— prolonged QRS complexes $\geq 120 \mathrm{~ms}$ in standard electrocardiography (ECG) before the implantation of the resynchronisation system;

— reduced left ventricular ejection fraction $\leq 35 \%$;

- life expectancy of over one year.

\section{Management scheme}

In patients implanted with CRT-D, telemonitoring of the device was implemented between the second and the fourth day after the implantation (before hospital discharge). The patients received Biotronik or Medtronic transmitters, enabling remote monitoring of the implanted device from the patients' houses. All patients were instructed in the working principles of the telemonitoring device and received training concerning its operation. The data from the device's memory were transmitted to data collection centres of individual companies through the telecommunications network as routine follow-ups or when initiated by alerts generated by the device. After processing, the data were made available to medical staff from the centre that performed the implantation. The data acquired through the company's website were analysed daily by trained medical and nursing personnel of an electrophysiology lab. The delay from the reception of a report to its analysis was $24 \mathrm{~h}$ on working days and up to $72 \mathrm{~h}$ during holidays. 
Devices manufactured by Biotronik were provided for $71 \%$ of the study population, while $29 \%$ received devices by Medtronic. In $97.3 \%$ of cases, the monitors were wireless, fully automatic, and capable of immediate data transmission whenever a pre-specified alert notification was fulfilled. Scheduled reports were automatically sent every month. The triggers for pre-specified emergency alert transmissions were as follows:

- detection of ventricular tachycardia (VT) or ventricular fibrillation episodes;

- CRT-D intervention (both low and high voltage ones);

- episode of ventricular arrhythmia with two or more highvoltage interventions;

- unsuccessful max. high voltage therapy;

- ventricular extrasystoles > 110/h;

- any episode of atrial fibrillation (AF), atrial flutter (AFL), or supraventricular tachycardia;

- mean HR during AF $>130 /$ min lasting $>10 \%$ of $24 \mathrm{~h}$;

- mean 24-h HR > 100/min;

- mean 24-h HR at rest $>80 / \mathrm{min}$;

- CRT pacing < 95\%;

- Elective Replacement Indicator (ERI) of End Of Service (EOS);

- device malfunction (device and lead integrity disorders, i.e. right ventricle lead impedance or sensing out of range, electrode noises, etc.).

Device alerts initiating transmission were divided into alerts resulting from device functioning irregularities (e.g. T-wave oversensing) and alerts caused by clinical abnormalities (e.g. episodes of CRT pacing $<95 \%$ or the occurrence of ventricular or supraventricular arrhythmia).

The all-cause mortality of the study population was assessed at the end of the follow-up period (mean 20.5 months).

\section{Statistical analysis}

The values of continuous variables are presented as arithmetic means \pm standard deviation (SD), while the values of qualitative variables are shown as numbers of cases and percentages. All statistical calculations were performed with the use of Statistica 6.0 software (Stat Soft, Tulsa, USA).

\section{RESULTS}

\section{Characteristics of the study population}

Men constituted $76 \%$ of the study population; the mean age was over 62 years. In $79 \%$ of patients, CRT-D devices were implanted as primary prevention of sudden cardiac death. Ischaemic aetiology of HF was found in $57.1 \%$ of patients; the average NYHA class was 2.75. In the analysed population, over $45 \%$ of patients experienced a myocardial infarction, $10.2 \%$ had stroke, over $28 \%$ underwent cardiac surgery, and $42.1 \%$ had glucose abnormalities. Initially, $40 \%$ of the patients suffered from AF (20\% paroxysmal, 20\% persistent). The characteristics of the study population are shown in Table 1.
Table 1. Characteristics of the study population

\begin{tabular}{lc}
\hline Male & $232(76 \%)$ \\
Age [years] & 62.6 \\
Mean NYHA class & 2.75 \\
Primary prevention of SCD & $241(79 \%)$ \\
Secondary prevention of SCD & $64(21 \%)$ \\
Ischaemic aetiology & $174(57.1 \%)$ \\
Non-ischaemic aetiology & $131(42.9 \%)$ \\
History of myocardial infarction & $139(45.5 \%)$ \\
Stroke & $31(10.2 \%)$ \\
Previous PCI & $125(40.9 \%)$ \\
Previous CABG & $49(16.1 \%)$ \\
Previous non-CABG cardiac surgery & $37(12.1 \%)$ \\
Previously implanted pacemaker & $113(37 \%)$ \\
Diabetes & $110(36.1 \%)$ \\
Impaired fasting glucose & $15(5 \%)$ \\
Impaired glucose tolerance & $3(1 \%)$ \\
Paroxysmal AF & $61(20 \%)$ \\
Persistent AF & $61(20 \%)$ \\
Paroxysmal AFL & $15(5 \%)$
\end{tabular}

Data are presented as number and percentage (in brackets); NYHA New York Heart Association; SCD — sudden cardiac death; PCI percutaneous coronary intervention; $C A B G$ - coronary artery bypass

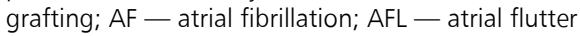

Table 2. Characteristics of the study population - echocardiographic data

\begin{tabular}{|lc|}
\hline LVEF [\%] & $26.8 \pm 8.7$ \\
LVEDD [mm] & $67 \pm 10$ \\
LVESD [mm] & $54.9 \pm 11.3$ \\
Moderate mitral regurgitation & $98(32.1 \%)$ \\
Severe mitral regurgitation & $40(13.1 \%)$ \\
\hline
\end{tabular}

Data are presented as mean \pm standard deviation or numbers and percentage (in brackets); LVEF — left ventricular ejection fraction; LVEDD - left ventricular end-diastolic diameter; LVESD — left ventricular end-systolic diameter

Analysis of the echocardiographic data revealed significant advancement of HF in the study population. The mean ejection fraction was $26.8 \%$; the left ventricular diastolic dimension was $67 \mathrm{~mm}$. Over $45 \%$ of patients had at least moderate mitral regurgitation. Detailed data are shown in Table 2.

\section{Assessment of the effectiveness of data transmission with the use of telemonitoring}

The effectiveness of report transmission among all analysed patients was very high and amounted to $98 \%$. In six cases (four — patients' non compliant — transmitters were switched 


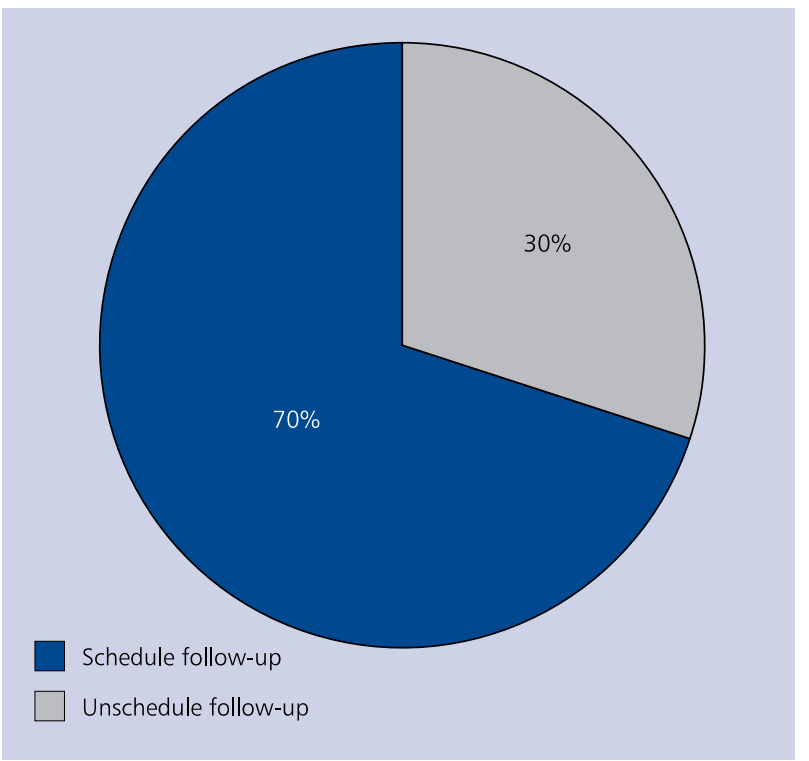

Figure 1. Types of daily analysed data

off, two - problems with connecting to a telephone line), the problems with transmission were solved by company technicians visiting the patients. During follow-up a total of 31,198 transmissions were received and analysed (average 50 reports a day), which constituted a mean of 4.9 transmissions per patient per month. Among these daily analyses, $30 \%$ were reports generated by the previously scheduled transmissions, while $70 \%$ were caused by unscheduled device alerts (Fig. 1).

The most common unscheduled alert transmissions were as follows: low percentage of CRT pacing < 95\% (63\%), episodes of VT (20.6\%), and the first time diagnosis of AF (15.7\%) (Table 3).

\section{Assessment of the influence of telemonitoring data on further therapy}

In $63.9 \%$ of patients, decisions based on the information obtained from telemonitoring reports were made to modify the therapy, refer the patients to cardiology or electrophysiology clinics, or hospitalise them urgently. The undertaken therapeutic activities included:

- optimisation of pharmacotherapy (beta-blocker uptitration, digoxin, amiodarone, or vitamin K antagonist introduction)

- qualification for atrioventricular node, VT, or AF ablation;

- CRT-D reprogramming;

- referral to the emergency room.

The most common medical reaction was device reprogramming (46.8\%); the causes included, among others, inadequate or unnecessary ICD interventions, low percentage of CRT pacing $<95 \%$, and chronic atrial arrhythmia. Pharmacotherapy was modified in $33.7 \%$ of patients; the
Table 3. The most common device alerts

\begin{tabular}{|lc|}
\hline Device alert & No. of patients (\%) \\
\hline CRT pacing $<95 \%$ & $192(63 \%)$ \\
VT episodes & $63(20.6 \%)$ \\
VF episodes & $13(4.3 \%)$ \\
AF de novo & $48(15.7 \%)$ \\
VES $>110 / h$ & $13(4.3 \%)$ \\
\hline
\end{tabular}

CRT — cardiac resynchronisation therapy; VT — ventricular tachycardia; VF — ventricular fibrillation; AF — atrial fibrillation; VES - ventricular extrasystoles

Table 4. Types of medical interventions in the study population

\begin{tabular}{|lc|}
\hline Medical intervention & No. of patients (\%) \\
\hline Any medical intervention & $195(63.9 \%)$ \\
Any pharmacotherapy modification & $103(33.7 \%)$ \\
Beta-blocker uptitration & $79(25.9 \%)$ \\
Digoxin introduction & $14(4.5 \%)$ \\
Amiodarone introduction & $6(1.9 \%)$ \\
Vitamin K antagonist introduction & $48(15.7 \%)$ \\
Qualification for AV node ablation & $25(8.1 \%)$ \\
Qualification for VT ablation & $9(2.9 \%)$ \\
Qualification for AF/AFL ablation & $5(1.6 \%)$ \\
Device reprogramming & $143(46.8 \%)$ \\
Referral to the emergency room & $3(1.0 \%)$ \\
\hline
\end{tabular}

AV — atrio-ventricular; VT — ventricular tachycardia; AF/AFL — atrial fibrillation/atrial flutter

Table 5. Number of interventions triggered by remote monitoring transmissions

\begin{tabular}{|lc|}
\hline No. of interventions & No. of patients (\%) \\
\hline No intervention & $110(36.1 \%)$ \\
1 intervention & $117(38.4 \%)$ \\
2 interventions & $42(13.8 \%)$ \\
3 interventions & $22(7.2 \%)$ \\
4 interventions & $7(2.3 \%)$ \\
$\geq 5$ interventions & $7(2.3 \%)$ \\
\hline
\end{tabular}

most common modifications were beta-blocker dose increase (25.9\%) and anticoagulant treatment introduction due to the first time diagnosis of AF (15.7\%). The remaining medical responses included referring patients for atrioventricular junction ablation (8.1\%) due to low percentage of CRT pacing despite optimal pharmacotherapy in patients with $\mathrm{AF}, \mathrm{VT}$ ablation $(2.9 \%)$, or $\mathrm{AFL} / \mathrm{AF}$ ablation in the case of paroxysmal forms of these arrhythmias (1.6\%). Table 4 shows the distribution of medical reactions in the study population. 
Among all patients requiring medical interventions, the majority of them required only one intervention during their follow-up time (38.4\%). Detailed data are presented in Table 5.

The analysis of long-term outcomes revealed that the all-cause mortality of the whole study population was $13 \%$ during a mean follow-up period of 20.5 months (Table 5).

The comparative analysis of data received both remotely and traditionally (through manual device interrogation) led to a final confirmation of the correct functioning of the telemetric system. In all cases of successfully transmitted reports, the quality of the received data was equal to the data acquired through device interrogation during routine follow-up visits at the clinic.

\section{DISCUSSION}

The main finding of this study is that daily based remote monitoring of CRT-D devices is feasible, safe, and easy to use in a population of consecutive HF patients. The success rate of transmitted data in our study was $98 \%$ and the quality of obtained information was equal to data traditionally elicited during interrogation of the devices.

Secondly, we have shown that as many as $70 \%$ of the 31,198 tele-transmissions were urgent and unscheduled, most of which (nearly 2/3 of cases) were transient episodes of low biventricular pacing, reflecting the key issue of proper functioning of the device, response to CRT and long-term outcomes.

Third, we have shown that $1 / 3$ of patients needed no intervention during the whole follow-up period, while surprisingly another $1 / 3$ required only one intervention, and in nearly $50 \%$ of those cases it was a device reprogramming only.

Therefore, the major advantage of day by day remote monitoring of a large population of HF patients seems to be a continuous "triage" of high-risk patients and selection of individuals who require urgent intervention.

\section{Assessment of the effectiveness of data transmission with the use of telemonitoring}

The present study revealed that the telemonitoring of implantable devices manufactured by Medtronic and Biotronik is highly effective. These systems are reliable and safe. Within the analysed population, successful transmission of the data required for remote CRT device monitoring was achieved in as many as 299 (98\%) patients. In six cases, the problems with transmission were solved by company employees visiting the patients. The high effectiveness was most likely influenced by the fact that the majority of devices transmitted the data automatically, i.e. without the participation of the patient. In order to achieve successful transmission, the patient was required to switch the device on and remain within its range for a sufficient amount of time once per day. The data available in the literature corroborate the good results of the functioning of teletransmission systems achieved in this study. Rakkinainen et al. [7] demonstrated 90\% transmission effectiveness in patients with implanted ICDs during a nine-month follow-up. All problematic transmissions took place during a test transmission, and the majority of issues were solved without the necessity to replace the transmitter (10 out of 12 cases); in two cases, the monitor had to be replaced due to problems with connecting it to a telephone line. Moreover, the cited work confirmed the ease of use of the monitor by the patient, with $80 \%$ of these patients performing the transmission themselves. The doctors performing transmission analyses also considered the system (over $97 \%$ of transmissions) to be user-friendly and easy to use. Similarly, Heidbüchel et al. [8] demonstrated a 99.5\% success rate in identifying device-associated problems and medical events with the use of teletransmission in patients with CRT or ICD devices.

The majority of daily reports in our study were unscheduled. Out of all daily transmissions, $70 \%$ were associated with alerts generated by the devices. These included both arrhythmic events (such as AF or ventricular arrhythmias) and the daily-updated parameters, which helped to predict or confirm the worsening of HF. The latter included reductions of CRT pacing percentages, increases in the daily number of ventricular extrasystoles, the mean HR, or decreases in the activity of the patient. The number of transmissions per patient per month was 4.9. Lazarus [9] demonstrated that, among 445 patients with CRT, during a follow-up of $7.2 \pm 4.9$ months, the number of transmissions was 2.1. This may stem from the differences in the programming of device alerts in the cited study, e.g. registration of AF episodes lasting over $2.5 \mathrm{~h}$, while the presented work registered shorter episodes, lasting $30 \mathrm{~min}$ or less. According to the data in the available literature, even short AF episodes increase the risk of thromboembolism in patients with risk factors. This points to the necessity of monitoring even several-minute-long episodes of such arrhythmias [10-12]. Similarly, different alert thresholds for the percentage of CRT $(90 \%$ in the study by Lazarus vs. 95\% in our study) could have resulted in a lower number of reports. According to the applicable guidelines [5], attempts should be made to achieve CRT pacing close to $100 \%$. The currently available monitoring systems enable the programming of alerts for decreases in pacing percentage to levels not higher than $95 \%$. It seems that this setting of the alert threshold is justified and correct in the management of patients with HF and implanted CRT-D devices.

The present work demonstrated that the quality of the successfully transmitted data was $100 \%$. The information acquired through remote transmission was identical to the information obtained during follow-up visits at the clinic. The above data and the data found in the literature confirm the high effectiveness of the acquired device parameters and clinical information updated on a daily basis. 
Assessment of the influence of telemonitoring data on further therapy

As part of the study, an attempt was made to assess the data acquired through teletransmissons from CRT devices and analyse their capabilities and influence on patient management. It was shown that as many as $63.9 \%$ of patients required at least one additional medical intervention apart from their routine follow-up visits at the cardiology clinic; the majority of those patients required a single intervention only (38.4\%). The most common intervention was device reprogramming (46.8\%), followed by pharmacotherapy modification, which included increasing the doses of beta-blockers and the introduction of digoxin, amiodarone, or antithrombotic drugs. Patients most frequently required uptitration of beta-blockers, e.g. due to the increased burden of supraventricular or ventricular arrhythmia, which often resulted in a decrease in the percentage of CRT pacing. The daily updated data concerning the average ventricular rhythm during sinus rhythm or AF could result in contacting the patient in order to increase the dose of beta-blockers. The RAPID-RF observational study [13], encompassing 863 patients with implanted CRT devices and supervised with the use of remote monitoring, assessed the types and frequency of alerts requiring medical interventions. The analysed reports included changes in patient body mass, alerts caused by device malfunctions, HF, as well as ventricular and supraventricular arrhythmias. It was demonstrated that at least one type of alert occurred in $75 \%$ of patients from the studied group. The majority of these alerts concerned changes in body mass (86.9\%). In $34 \%$ of patients, the alerts were not associated with body mass measurements; $45 \%$ of these patients required a single intervention. The lower number of interventions in the cited study in comparison to our population may be associated with its shorter follow-up period. Moreover, only $15 \%$ of the patients in the RAPID-RF study were initially diagnosed with AF or AFL. In our study, the interventions associated with the monitoring of patients with supraventricular arrhythmias constituted a significant portion of all interventions. Even though the influence of telemonitoring on the frequency of conventional visits at the clinic was not analysed, the obtained data suggest that the number of unscheduled visits increased in the studied population. All patients requiring, for example, device reprogramming and some patients requiring pharmacotherapy modification had to pay additional visits to the clinic, which would not have taken place if they had not been called and summoned by the telemonitoring staff. These data are in accordance with the TRUST study [14], in which the number of unscheduled visits was statistically significantly higher in remotely monitored patients during a 12-month follow-up.

On the basis of the conducted analysis, it may be concluded that the telemonitoring of implantable devices is useful for the supervision of patients with advanced $\mathrm{HF}$ and implanted CRT. It provides useful data, which may indicate the progression of $\mathrm{HF}$, intensification of arrhythmia, both ventricular and supraventricular, or the proper functioning of the implanted system, enabling the selection of patients requiring closer supervision and more frequent visits.

\section{CONCLUSIONS}

Our study demonstrates that remote monitoring of implantable devices is feasible, safe, and effective in supervising patients with CRT-D devices. Continuous, day by day monitoring of CRT-D devices results in as many as 70\% of unscheduled transmissions, most of which are associated with daily variations of crucial CRT parameters. Nearly $2 / 3$ of patients need at least one intervention during follow-up period; however, in $1 / 3$ of them only one intervention is required (reprogramming of the device in almost $50 \%$ of cases). Daily-based remote monitoring of a large population of HF patients allows continuous "triage" of high-risk patients and selection of individuals who require urgent intervention.

Conflict of interest: Agnieszka Liberska, Michał Mazurek, Stawomir Pluta, Adam Sokal, Ewa Jędrzejczyk-Patej, Katarzyna Przybylska-Siedlecka, Oskar Kowalski, Radosław Lenarczyk, Monika Kozieł, Stanisław Morawski, Patrycja Pruszkowska - Consultant fees from Boston Scientific, Biotronik, Medtronic, and St. J. Medical; Zbigniew Kalarus — On speakers' bureaus for Pfizer, Elli-Lilly, Boehringer-Ingelheim, Abbott, Bayer, travel expenses to cardiology congresses: St. J. Medical, Adamed, advisory committee: Boehringer-Ingelheim, Amgen, Astra Zeneca.

\section{References}

1. Wilkoff BL, Auricchio A, Brugada J et al. HRS/EHRA Expert Consensus on the Monitoring of Cardiovascular Implantable Electronic Devices (CIEDs): Description of Techniques, Indications, Personnel, Frequency and Ethical Considerations Developed in partnership with the Heart Rhythm Society (HRS) and the European Heart Rhythm Association (EHRA); and in collaboration with the American College of Cardiology (ACC), the American Heart Association (AHA), the European Society of Cardiology (ESC), the Heart Failure Association of ESC (HFA), and the Heart Failure Society of America (HFSA). Endorsed by the Heart Rhythm Society, the European Heart Rhythm Association (a registered branch of the ESC), the American College of Cardiology, the American Heart Association. Europace, 2008; 10: 707-725.

2. Slotwiner D, Varma N, Akar JG et al. HRS Expert Consensus Statement on remote interrogation and monitoring for cardiovascular implantable electronic devices. Heart Rhythm, 2015; 12: e69-e100.

3. Dubner S, Auricchio A, Steinberg JS et al. ISHNE/EHRA expert consensus on remote monitoring of cardiovascular implantable electronic devices (CIEDs). Europace, 2012; 14: 278-293. doi: 10.1093/europace/eur303.

4. Eucomedwww.eucomed.org/uploads/_medical_technology/facts _figures/CRM_Graphs_2015.pdf.

5. Brignole M, Auricchio A, Baron-Esquivias G et al. 2013 ESC guidelines on cardiac pacing and cardiac resynchronization therapy: the task force on cardiac pacing and resynchronization therapy of the European Society of Cardiology (ESC). Developed in collaboration with the European Heart Rhythm Association (EHRA).European Society of Cardiology (ESC); European Heart Rhythm Association (EHRA). Europace, 2013; 15: 1070-1118. doi: 10.1093/eurheartj/eht150. 
6. Hindricks G, Taborsky M, Glikson $\mathrm{M}$ et al. Implant-based multiparameter telemonitoring of patients with heart failure (IN-TIME): a randomised controlled trial. Lancet, 2014; 384: 583-590. doi: 10.1016/S0140-6736(14)61176-4.

7. Raatikainen MJ, Uusimaa P, van Ginneken MM et al. Remote monitoring of implantable cardioverter defibrillator patients: a safe, time-saving, and cost-effective means for follow-up. Europace, 2008; 10: 1145-1151. doi: 10.1093/europace/eun203.

8. Heidbüchel H, Lioen P, Foulon S et al. Potential role of remote monitoring for scheduled and unscheduled evaluations of patients with an implantable defibrillator. Europace, 2008; 10: 351-357. doi: 10.1093/europace/eun010.

9. Lazarus A. Remote, wireless, ambulatory monitoring of implantable pacemakers, cardioverter defibrillators, and cardiac resynchronization therapy systems: analysis of a Worldwide Database. PACE, 2007; 30: S2-S12.

10. Hohnloser SH, Capucci A, Fain E et al. Asymptomatic atrial fibrillation and Stroke Evaluation in pacemaker patients and the atrial fibrillation Reduction atrial pacing Trial (ASSERT). Am Heart J, 2006; 152: 442-447.

11. Healey JS, Connolly SJ, Gold MR et al. Subclinical atrial fibrillation and the risk of stroke. N Engl J Med, 2012; 366: 120-129. doi: 10.1056/NEJMoa1105575.

12. Santini M, Gasparini M, Landolina M et al. Device-detected atrial tachyarrhythmias predict adverse outcome in real-world patients with implantable biventricular defibrillators. J Am Coll Cardiol, 2011; 57: 167-172. doi: 10.1016/j. jacc.2010.08.624.

13. Boehmer JP, Saxon LA, Lobban J et al. Clinician Response to Remote Active Monitoring in Patients with Heart Failure: Results of the RAPID-RF Trial. J Inn Cardiac Rhythm Management, 2014; 5: 1551-1560.

14. Varma N, Epstein AE, Irimpen A et al. Efficacy and safety of automatic remote monitoring for implantable cardioverter-defibrillator follow-up. Circulation, 2010; 122: 325-332. doi: 10.1161/CIRCULATIONAHA.110.937409.

\title{
Codzienna, telemetryczna opieka nad pacjentami $\mathbf{z}$ implantowanym rozrusznikiem resynchronizującym: pierwsze polskie doświadczenia
}

\author{
Agnieszka Liberska, Oskar Kowalski, Michał Mazurek, Radosław Lenarczyk, Ewa Jędrzejczyk-Patej, \\ Katarzyna Przybylska-Siedlecka, Monika Kozieł, Stanisław Morawski, Tomasz Podolecki, \\ Jacek Kowalczyk, Patrycja Pruszkowska, Sławomir Pluta, Adam Sokal, Zbigniew Kalarus
}

Klinika Kardiologii, Wrodzonych Wad Serca i Elektroterapii, Śląski Uniwersytet Medyczny, Śląskie Centrum Chorób Serca, Zabrze

\section{Streszczen ie}

Wstęp: W opiece nad chorymi z niewydolnością serca (HF) i wszczepionym układem stymulującym jednym z najważniejszych elementów jest stała kontrola funkcji urządzenia, częsta ocena stanu klinicznego pacjenta oraz dostosowanie terapii indywidualnie do poszczególnych chorych. W związku z szybko rosnącą w ostatnich latach liczbą pacjentów z kardiostymulatorami, kardiowerterami-defibrylatorami (ICD) i rozrusznikami resynchronizującymi (CRT) coraz trudniejsza staje się konwencjonalna kontrola w ramach poradni specjalistycznych. Dlatego też coraz większym zainteresowaniem cieszy się telemonitoring. Dzięki rozwojowi technologii możliwe stało się zdalne, codzienne monitorowanie urządzeń przy użyciu systemów do teletransmisji.

Cel: Celem pracy była ocena skuteczności transmisji i możliwości wykorzystania pozyskanych drogą telemetryczną danych w dalszym postępowaniu klinicznym u pacjentów z HF i wszczepionym CRT-D.

Metody: Analizą objęto 305 kolejnych chorych z przewlekłą HF, w II-IV klasie czynnościowej wg New York Heart Association (NYHA), leczonych z zastosowaniem CRT-D firmy Biotronik lub Medtronic w latach 2006-2012. U chorych po implantacji 
CRT-D w 2.-4. dniu po zabiegu wdrażano telemonitoring wszczepionego urządzenia. Rutynowe raporty były wysyłane automatycznie co miesiąc. Alarmy urządzenia powodujące wysyłanie raportu nieplanowego zdefiniowano jako: wystąpienie epizodu częstoskurczu komorowego i migotania komór, interwencje CRT-D, epizody arytmii nadkomorowych, spadek odsetka stymulacji CRT < 95\%, średnia liczba ekstrasystolii komorowej > 110 na godzinę, średni rytm komór, średni i maksymalny rytm komór podczas migotania przedsionków (AF), alarmy Elective Replacement Indicator (ERI) i End of Servce (EOS) oraz inne nieprawidłowości działania systemu. Śmiertelność całkowitą analizowanej populacji oceniono po zakończeniu okresu obserwacji.

Wyniki: Dane dotyczące wszczepionego urządzenia uzyskano z jednoośrodkowego, prospektywnego rejestru. Spośród badanej populacji 71\% osób otrzymało urządzenia firmy Biotronik, a 29\% pacjentów — firmy Medtronic; 97,3\% urządzeń było w pełni automatyczne. Śmiertelność całkowita badanej populacji w okresie obserwacji (średnio 20,5 miesiąca) wyniosła 13\%. Grupa badana składała się w 76\% z mężczyzn, średni wiek wynosił 62,6 roku. W ramach prewencji pierwotnej nagłego zgonu sercowego CRT-D implantowano 79\% chorym. Etiologię niedokrwienną HF stwierdzono u 57,1\% osób, a średnia wartość NYHA wynosiła 2,75. Wśród wszystkich analizowanych pacjentów skuteczność wysyłania raportów była bardzo wysoka i wynosiła $98 \%$. W okresie obserwacji otrzymano i przeanalizowano 31198 raportów. Codziennej analizie podlegało średnio 50 raportów, co stanowi średnio 4,9 transmisji na pacjenta na miesiąc. Wśród tych codziennych analiz $30 \%$ było raportami wygenerowanymi wg zaplanowanego wcześniej kalendarza zdalnych kontroli, a 70\% spowodowanymi alarmem urządzenia. Wykazano również prawidłowe działanie systemu. W przypadku skutecznego wysłania raportu jakość otrzymanych danych wynosiła 100\%, tzn. dane otrzymanie poprzez teletransmisję były tożsame z otrzymanymi w trakcie interrogacji urządzenia podczas rutynowej kontroli w poradni przyklinicznej. U 63,9\% osób na podstawie informacji uzyskanych z raportów telemonitoringu podejmowano decyzję o konieczności modyfikacji terapii, skierowania chorego do poradni kardiologicznej, elektrofizjoloficznej lub do pilnej hospitalizacji. Najczęstszą reakcją medyczną była konieczność przeprogramowana urządzenia (46,8\%). Modyfikacja farmakoterapii obejmowała 33,7\% pacjentów, na które składało się zwiększenie dawki leku beta-adrenolitycznego (25,9\%), włączenie leczenia przeciwkrzepliwego z powodu stwierdzenia de novo AF (15,7\%), włączenie digoksyny (4,5\%) i amiodaronu $(1,9 \%)$. Pozostałe reakcje obejmowały skierowanie chorych na ablację łącza przedsionkowo-komorowego $(8,1 \%)$ z powodu niskiego odsetka stymulacji CRT mimo optymalnej farmakoterapii u osób z utrwalonym AF, ablacji częstoskurczu komorowego $(2,9 \%)$ czy ablacji migotania i trzepotania przedsionków w postaciach napadowych tych arytmii (1,6\%). Spośród pacjentów wymagających interwencji lekarskiej największa liczba chorych wymagała 1 interwencji w okresie obserwacji (38,4\%).

Wnioski: W pracy wykazano, że zdalny monitoring urządzeń wszczepialnych jest bezpieczną, efektywną i skuteczną metodą kontroli nad pacjentami z wszczepionym CRT-D. Zastosowanie zdalnego monitorowania chorych z objawową HF leczonych za pomocą CRT-D umożliwia wczesne wykrywanie nieprawidłowości technicznych i skuteczne kontrolowanie istotnych parametrów klinicznych, co pozwala na optymalizację i wdrażanie adekwatnych terapii. Codzienne monitorowanie dużej grupy chorych z HF pozwala na wyselekcjonowanie pacjentów wysokiego ryzyka, wymagających pilnej interwencji.

Słowa kluczowe: telemonitoring, terapia resynchronizująca, niewydolność serca

Kardiol Pol 2016; 74, 8: 741-748 